\title{
Tatiana Czerska
}

\author{
Uniwersytet Szczeciński \\ ORCID: 0000-0002-3752-5498
}

\section{Przemieszczenia Eleonory Kalkowskiej}

\author{
Anna Dżabagina \\ Kalkowska: Biogeografia \\ (Gdańsk: Fundacja Terytoria Książki, 2020)
}

Bardzo długo Eleonora Kalkowska funkcjonowała w historii teatru i historii literatury przede wszystkim jako autorka kilku sztuk zaliczanych do nurtu Zeittheater okresu Republiki Weimarskiej. Ukoronowaniem wieloletnich prac badawczych nad jej biografią i twórczością są dwie książki Anny Dżabaginy: edycja krytyczna zbioru debiutanckich opowiadań Głód życia', która ukazała się w 2016, oraz wydana cztery lata później monografia zatytułowana Kalkowska: Biogeografia. Publikacja ta, jak czytamy we wstępie, powstała z potrzeby

\footnotetext{
${ }^{1}$ Eleonora Kalkowska, Głód życia, oprac. Anna Dżabagina (Gdańsk: słowo/obraz terytoria, 2016).
} 
scalenia dorobku pisarki i całościowej analizy jej dzieła. Warszawska badaczka poszukuje powodów marginalizacji Kalkowskiej zarówno w niemieckiej, jak i polskiej historii literatury. Pyta o przyczyny wymazania autorki Sprawy Jakubowskiego z unarodowionych kanonów literackich. W odpowiedzi wskazuje przede wszystkim na jej liczne i częste przemieszczenia, „niejednoznaczną, wielopozycyjną przynależność narodową"2, a także powstałe jeszcze za jej życia schematy recepcyjne. Dżabagina krytycznie podchodzi do prób narzucenia pisarce narodowych afiliacji, twierdząc, że twórczość Kalkowskiej wymaga wyjścia poza narodowy paradygmat:

Moim celem jest z jednej strony umiejscowienie twórczości Kalkowskiej na mapie ponadnarodowych kontekstów i konstelacji, w świetle których jej dzieło stanowi ważne, choć zapoznane, ogniwo modernistycznej produkcji. Z drugiej strony chcę pokazać, w jaki sposób niejednoznaczna przynależność narodowo-kulturowa Kalkowskiej interferowała z recepcją jej twórczości, a także ukształtowała jej sposób funkcjonowania w dyskursie historycznoliterackim (6).

Przypomnijmy, że Eleonora Kalkowska pochodziła z polsko-niemieckiej rodziny o teatralnych tradycjach. Mieszkała między innymi w Warszawie, Wrocławiu (Breslau), Petersburgu, Paryżu (gdzie studiowała nauki przyrodnicze na Sorbonie), Krakowie, Berlinie, ostatnie lata życia spędziła w Anglii i Szwajcarii³. Odebrała wielokulturowe i wielojęzyczne wychowanie. Oddajmy głos samej pisarce:

Być może dlatego, że mieszanka krwi w mych żyłach - niemieckiej, polskiej, ale również w mniejszym stopniu francuskiej i szwedzkiej - wywołała we mnie stan napięcia, który swoją korelację, rozładowanie - a przez to w pewnym sensie rozwiązanie - mógł odnaleźć wyłącznie w twórczości dramatycznej.

Być może dlatego, że pochodzę z rodziny, która dała scenie wielu wspaniałych aktorów, a która atawistycznie opętała mnie namiętnością do teatru i słowo poetyckie ożywa dla mnie tylko wtedy, kiedy towarzyszy mu dźwięk.

Być może również dlatego, że moje nastawienie do świata coraz silniej skłaniało się ku stanowi „nienawistnej miłości” - mieszanki pogardy, odrazy i zgrozy ze swojego rodzaju podziwem i uwielbieniem - w którym, pomimo całego przerażenia okrucieństwem dziejów ludzkich i uwikłaniem człowieka w sytuację bez wyjścia, pełna byłam najczystszego i najprawdziwszego zachwytu nad każdorazową próbą wyrażenia siebie czy świata, podejmowaną przez jednostkę. Zachwyt ten znajdował swój najpełniejszy

${ }^{2}$ Anna Dżabagina, Kalkowska: Biogeografia (Gdańsk: Fundacja Terytoria Książki, 2020), 5. Kolejne cytaty lokalizowane są w tekście głównym w nawiasach.

3 Podstawowe fakty z biografii Eleonory Kalkowskiej referuję na podstawie prezentowanej pracy oraz artykułów poświęconych pisarce, o których będzie mowa w dalszej części. 
wyraz tylko w fizycznej bliskości sceny, w kreacji prawdziwych, poruszających się, oddychających, przemawiających ludzi... ${ }^{4}$

Najgłośniejsze sztuki Kalkowskiej należały do dominującego w Republice Weimarskiej nurtu Zeittheater, poruszającego na scenie najistotniejsze kwestie polityczne i społeczne swego czasu ${ }^{5}$. Trudno zrozumieć, dlaczego jej utworów nie wystawiały w międzywojniu polskie zespoły, z wyjątkiem Teatru Ateneum, podążające śladem niemieckiego teatru zaangażowanego. Zdaniem Rafała Węgrzyniaka w dwudziestoleciu nie było polskiej dramatopisarki o podobnym temperamencie publicystycznym i równie nowoczesnym warsztacie ${ }^{6}$. Barbara Michalczyk, interpretując prapremierę Sprawy Jakubowskiego z warszawskiego Ateneum oraz jej recepcję w ówczesnej prasie, zauważa, że w Polsce dramaty interwencyjne tworzyły właściwie tylko kobiety, między innymi Marcelina Grabowska czy Maria Morozowicz-Szczepkowska: „Eleonora Kalkowska była bez wątpienia, jako zaangażowana feministka, przykładem płynącym z zagranicy, potencjalnie inspirującym dla polskich twórczyń"7.

Dramaty Kalkowskiej nie były w Polsce wznawiane ani grane po wojnie. O zgromadzenie i wydanie jej dorobku dopominał się w 1972 roku Zbigniew Herbert w szkicu opublikowanym w „Twórczości”. Tekst ten przeszedł jednak bez echa, został przedrukowany dopiero w $2001 \mathrm{w}$ zbiorze Węzeł gordyjski ${ }^{8}$. Wzbudził wówczas zainteresowanie teatrolożki Jagody Hernik Spalińskiej, która w 2005 na łamach „Dialogu” ogłosiła szkic prezentujący biografię Kalkowskiej i jej sztuki teatralne, a następnie przygotowała edycję dwóch dramatów - Sprawy Jakubowskiego i Doniesień drobnych - z obszernym wprowadzeniem historycznym 9 . Jedyna do tej pory monografia poświęcona pisarce - czyli wydana w 2009 książka Die Zeitstücke von Eleonore Kalkowska Agnes Trapp ${ }^{10}$ - omawia tylko trzy dramaty z jej bogatego dorobku. Kolejnym momentem przywracającym pamięć o niej było włączenie Kalkowskiej do projektu badawczo-popularyzatorskiego

4 Eleonora Kalkowska, „Dlaczego zostałam dramatopisarką?”, tłum. Barbara Bernhardt, w: Sprawa Jakubowskiego, Doniesienia drobne: Dramaty (Warszawa: Instytut Teatralny im. Zbigniewa Raszewskiego, 2005), 19.

5 Idea Zeittheater wywodziła się z założeń niemieckiej awangardy teatralnej pierwszych dziesięcioleci xx wieku: „Propagowana przez Erwina Piscatora koncepcja teatru reagującego na zdarzenia «tu» $\mathrm{i}$ «teraz», intensywnie zaangażowana w spory ideologiczne, obronę uciśnionych i uciszanych, wykorzystująca innowacyjne tworzywo teatralne przy konstrukcji faktomontażu: elementy kronik filmowych, autentyczne fotografie, fragmenty prasowych doniesień, została zaadaptowana w Polsce dzięki Leonowi Schillerowi", Justyna Kowal, wstęp do: Teatr zaangażowany w Polsce ina świecie: Wrocławski Zeittheater, red. Magdalena Gołaczyńska, Justyna Kowal i Piotr Rudzki (Kraków: Universitas, 2021), 6.

6 RafałWęgrzyniak, „Eleonora Kalkowska”, Zeszyty Literackie 93, z.1 (2006): 209-211.

7 Barbara Michalczyk, ,Sprawy polsko-niemieckie wokół Sprawy Jakubowskiego Eleonory Kalkowskiej," w: Gołaczyńska et al., Teatr zaangażowany w Polsce ina świecie, 222.

8 Zbigniew Herbert, „Eleonora Kalkowska”, w: Węzeł gordyjski oraz inne pisma rozproszone 1948-1998 (Warszawa: Biblioteka „Więzi", 2001), 524-525. Pierwodruk: Twórczość, nr 7 (1972): 156

9 Jagoda Hernik Spalińska, "Eleonora Kalkowska - przywracanie pamięci”, w: Kalkowska, Sprawa Jakubowskiego, 3-18.

${ }^{10}$ Agnes Trapp, Die Zeitstücke von Eleonore Kalkowska (München: Martin Meidenbauer, 200g). 
dotyczącego polskich dramatopisarek XIX i xx wieku „Dziwy polskie - kobiece pisanie, kobiece praktyki w teatrze" przygotowanego przez Grupę Artystyczną Teraz Poliż. W październiku 2015 w Teatrze Współczesnym w Szczecinie publiczności zaprezentowana została sztuka Doniesienia drobne.

Należy podkreślić, że książka Anny Dżabaginy nie jest jedyną próbą przypomnienia i omówienia całego dorobku Eleonory Kalkowskiej oraz rekonstrukcji jej biografii. Próbę uporządkowania dotychczasowego stanu badań na temat pisarki w Niemczech i w Polsce podjęła w 2015 roku germanistka Joanna Ławnikowska-Koper. Ona także, podobnie jak Dżabagina, akcentuje rozwój artystyczny Kalkowskiej: „od poezji miłosnej [...] przez lirykę antywojenną [...] aż po dramat społeczny okresu weimarskiego”. Podkreśla „ponadnarodową wartość pisarstwa” tworzącej po niemiecku autorki, „którego istotą pozostaje idea sprawiedliwości społecznej i obrona człowieczeństwa jednocześnie z pozycji humanistycznych, chrześcijańskich i feministycznych"”. Wiele nieznanych wcześniej faktów z życia Kalkowskiej pojawia się po raz pierwszy w szkicu Ławnikowskiej-Koper (artykuł ten został tylko dwukrotnie przytoczony w prezentowanej monografii).

Inspiracje metodologiczne Dżabagina czerpie głównie ze studiów transkulturowych, zwłaszcza z koncepcji transferów kulturowych i badań nad modernizmem uchodźczym (exile studies), oraz z krytyki feministycznej z jej polityką umiejscowienia i zaznaczeniem nieobecności kobiecej twórczości w kanonie modernizmu uchodźczego. Najczęściej odwołuje się do badań Pascale Casanovy, szukającej zasad funkcjonowania transnarodowego pola literackiego, oraz do koncepcji „lokalnie ugruntowanego internacjonalizmu metropolii" (16) Cristianne Miller. Równie istotne dla Dżabaginy są studia rozwijane w ramach zwrotu przestrzennego i geopoetyki. Podtytuł (Biogeografia) odwołuje się do prac Elżbiety Rybickiej' ${ }^{12}$, która używa pojęcia auto/bio/geo/grafii. Neologizm ten w intencji autorki Geopoetyki nawiązuje do tradycji pisarstwa autobiograficznego i biograficznego, w których historia człowieka rozumiana jest poprzez miejsca geograficzne's. Jak podkreśla Rybicka, analiza geobiograficzna nie obejmuje jednak tylko ruchu w przestrzeni geograficznej i pokonywania granic terytorialnych, ale uwzględnia także wewnętrzne przemiany w osobowości ${ }^{14}$. Kategoria przemieszczenia $\mathrm{z}$ kolei w ujęciu Rybickiej dotyczy „uprzestrzennienia czasu lub wpisania czasu w przestrzen"”,

11 Joanna Ławnikowska-Koper, „W obronie sprawiedliwości: Eleonora Kalkowska (1883-1937) - między Warszawą a Berlinem", Roczniki Humanistyczne 63, z. 5 (2015): 143, https://doi.org/10.1829o/rh.2015.63.5-10

12 Biogeografia (bíos - życie, gé-ziemia, gráphein - pisać) - nauka z pogranicza biologii i geografii, zajmująca się badaniem rozmieszczenia przestrzennego roślin, grzybów i zwierząt na Ziemi. Rybicka, śledząc podobieństwa między literaturą a geografią, zwraca uwagę na interdyscyplinarność naukowych poszukiwań oraz wieloaspektowość związków między pozornie odległymi polami semantycznymi. Zob. Elżbieta Rybicka, Geopoetyka: Przestrzeń i miejsce we współczesnych teoriach i praktykach literackich (Kraków: Universitas, 2014).

13 Elżbieta Rybicka, „Auto/bio/geografie", Białostockie Studia Literaturoznawcze, nr 4 (2013): 11.

14 Rybicka, „Auto/bio/geografie”, 12.

15 Rybicka, Geopoetyka, 286. 
ponieważ „miejsce i literatura potrzebują się wzajemnie; przestrzeń wydrążona z pamięci odzyskuje swą historię i przeszłość (nawet jeśli ma ona niekiedy status imaginacyjny), literatura z kolei zyskuje zakotwiczenie w geografii i historii”"16.

W ujęciu Dżabaginy teksty Eleonory Kalkowskiej, podobnie jak ich autorka, zdają się krążyć, przemieszczać się, zmieniać swój status, otwierać się na nowe konteksty, które z kolei stymulują formę ich przekazu. Warto przywołać ustalenia innej badaczki transkulturowości, Doroty Utrackiej, która zauważa, że ustawiczne przemieszczenia w obszarze rozproszonych tożsamości pozwalają

czytać współczesne teksty kultury jako obszar swobodnej wymiany tworzyw artystycznych, intermedialną grę kodów, służącą interpretacyjnej otwartości i ruchliwości znaczeń. Wędrowne losy tekstów kultury nie zakładają terytorializacji, lecz stałe przemieszczenie ${ }^{17}$.

Przywoływane przesunięcia (przemieszczenia) interpretacyjne stanowią więc immanentną część praktyk odbioru i poszerzają perspektywę ujęcia spuścizny Kalkowskiej. W tak zarysowanym polu badawczym kluczowym zadaniem, jakie wyznacza sobie Dżabagina, staje się rekonstrukcja sieci powiązań pisarki i umieszczenie jej dzieła na unikatowej, ponadnarodowej mapie kontekstów: młodopolskiego Paryża, weimarskiego Berlina, uchodźczego Londynu.

Omawiana książka jest niewątpliwie efektem szeroko zakrojonej kwerendy i skrupulatnej lektury źródeł. Dżabagina korzysta z ogromnej liczby materiałów pisanych i ikonograficznych (publikacja zawiera liczne fotografie oddające realia i klimat epoki, kopie dokumentów dotyczących samej pisarki i bliskich jej osób), analizuje je i poddaje krytyce, polemizuje z nimi, przedstawia własne odkrycia i interpretacje. Nie można zaprzeczyć, że Kalkowska stanowi efekt benedyktyńskiej pracy w archiwach niemieckich (przede wszystkim w Deutsche Literaturarchiv w Marbach, gdzie przechowywane są manuskrypty Kalkowskiej, maszynopisy niedrukowanych dramatów i innych utworów, oraz w Akademie der Künste w Berlinie), polskich (między innymi Archiwum Akt Nowych i Archiwum Akt Głównych w Warszawie) i zagranicznych (Österreichische Nationalbibliothek w Wiedniu, Государственный архив литературы и искусства w Moskwie).

Dżabagina wpisuje życie i twórczość swojej bohaterki w szerokie konteksty artystyczne, historyczne, obyczajowe, polityczne. Zgromadzone prace teoretyczne stwarzają możliwości spojrzenia $\mathrm{z}$ różnych punktów widzenia i na samą Kalkowską, i na jej dzieła. Część pierwsza (Migracje) opisuje lata 1883-1918, czyli okres dobrowolnych przemieszczeń i etap nomadycznych poszukiwań (zarówno

\footnotetext{
${ }^{16}$ Elżbieta Rybicka, „Miejsce, pamięć, literatura (w perspektywie geopoetyki)”, Teksty Drugie, nr 1-2 (2008): 26.

17 Dorota Utracka, „Parodie transmedialne: Tekst kultury jako kod nomadyczny”, w: Nomadyzm i nomadologia: Rozważania i analizy, red. Aleksander Kiklewicz i Arkadiusz Dudziak (Olsztyn: Centrum Badań Europy Wschodniej, 2018 ), 8o.
} 
artystycznych, jak i geograficznych). W tej partii pracy badaczka podejmuje próbę rekonstrukcji, jak to nazywa, „przedakcji”: zajmuje się genealogią pisarki, jej rodzinnymi koligacjami. Dużo uwagi poświęca postaci ciotecznej babki Eleonory ze strony matki, Anny Marii Stegemann, urodzonej w ówczesnym Stettin, dzisiejszym Szczecinie (nie wiadomo dlaczego autorka używa wyłącznie polskiej nazwy miasta), światowej sławy aktorki i śpiewaczki operowej występującej jako Felicita von Vestvali, która słynęła $\mathrm{z}$ odtwarzania na scenie ról męskich (zamieszczone w książce portrety ukazują ją nie tylko w męskich strojach, ale także z wąsikiem) i nie ukrywała swojego homoseksualizmu.

Wiele miejsca zajmuje prezentacja i szczegółowa analiza twórczości literackiej Kalkowskiej, zwłaszcza tej pozostającej w cieniu dramatów, oraz jej recepcji krytycznej. Obszernej analizie poddany zostaje napisany po polsku debiutancki tom opowiadań Głód życia wydany w 1903. Dżabagina zestawia go z Narcyzem Zofii Nałkowskiej, dostrzegając w obu przejawy nietzscheańskiego witalizmu oraz kreacje nadkobiety, charakterystyczne dla młodopolskich pisarek. Dopiero w 1912 pojawia się kolejna książka Kalkowskiej, niemieckojęzyczny tym razem tom poezji wydany w niemieckim wydawnictwie, co zdaniem Dżabaginy miałoby być efektem chłodnego przyjęcia w Polsce pierwszej publikacji. Następny tom poetycki Der Rauch des Opfers (Dymy ofiarne) stanowi reakcję na wojnę światową oraz wyraz pacyfistycznych przekonań Kalkowskiej - ten antywojenny manifest analizowany jest na tle związków między feminizmem a pacyfizmem, rozwijających się na przełomie XIX i xx wieku.

W drugiej części (Przystań), obejmującej lata zakorzenienia i rozkwitu kariery Kalkowskiej, badaczka rekonstruuje jej działalność w modernistycznym, kosmopolitycznym Berlinie okresu weimarskiego (1919-1933): starania o to, by jej dramaty trafily na scenę, oraz największe sukcesy w karierze przerwanej przez dojście NSDAP do władzy. Posiłkując się pracą Kobiety $z$ lewego brzegu Shari Benstock, dotyczącą Paryża początku xx stulecia, oraz Culture of Modernism Cristianne Miller, Dżabagina analogicznie stara się naszkicować portret środowiska kobiecej bohemy Berlina lat dwudziestych, w którym najważniejszą rolę odgrywały przedstawicielki sztuk wizualnych. Otrzymujemy nakreślony z rozmachem obraz kobiecej subkultury, sieci kontaktów, kobiecych organizacji samopomocowych działających w tej metropolii:

Berlińska afiliacja - zupełnie innego rodzaju niż ta dawana chociażby przez przynależność narodową - pozwalała kobietom zaczynającym swoją drogę na marginesach (imigrantkom, Żydówkom, lesbijkom i nie tylko) rościć sobie prawo do zaistnienia w przestrzeni publicznej. Skłaniała także do tworzenia własnych enklaw wolności, artystycznej ekspresji, instytucji oraz mediów reprezentacji. Sprzyjała również powstawaniu przyjacielskich i instytucjonalnych konstelacji, w obrębie których niebagatelną rolę odgrywała swego rodzaju siostrzana samopomoc. Nie miała ona zresztą wymiaru wyłącznie symbolicznego, a historia Kalkowskiej jest doskonałą ilustracją tego zjawiska (167). 
Z tego tła wyłania się sylwetka Eleonory Kalkowskiej, pozostającej według badaczki w ścisłym kontakcie z czołowymi przedstawicielkami bohemy artystycznej Berlina, z rzeźbiarką Milly Steger u boku. Dżabagina pokazuje Kalkowską aktywnie zabiegającą o uznanie w świecie literackim i teatralnym (między innymi dzięki protektoratowi znanej duńskiej pisarki Karin Michaëlis). Starania te nie zawsze przynosiły efekty, jak choćby w przypadku sztuki o carycy Katarzynie Wielkiej. Tym dramatem poświęconym postaci, która w niechlubny sposób zapisała się w dziejach Polski, autorka, zdaniem biografki, dowiodła, że wyzbyła się narodowych zobowiązań. W kolejnych sztukach Kalkowskiej widać już zwrot ku teatrowi zaangażowanemu i interwencyjnemu. To one właśnie spotykają się z entuzjastycznym przyjęciem i przynoszą wreszcie upragniony sukces. Jednocześnie, wpisując się w lewicową narrację, narażają autorkę na gwałtowne ataki ze strony skrajnych nacjonalistów ${ }^{18}$.

Dżabagina ukazuje Kalkowską rozdartą między narzuconą jej rolą „agentki polskiej sprawy” (125) i walką o „uznanie w światowej republice literatury” (18). Barbara Michalczyk podkreśla złożoność zagadnienia recepcji polskiej inscenizacji Sprawy Jakubowskiego i dowodzi, że trudno było oczekiwać innej niż antyniemiecka reakcji:

W ujęciu autorki dramat miał być chrześcijańskim oraz humanitarnym głosem przeciwko stosowaniu kary śmierci, wpisywał się także w nurt protestów, jakie podnieśli czołowi niemieccy intelektualiści [...] w szerokim ujęciu został sprowadzony do konfliktu pomiędzy Niemcami a Polakami, co wynikało nie tylko ze sposobu przedstawienia bohaterów, ale także z napiętych stosunków pomiędzy krajami oraz bieżącej sytuacji politycznej ${ }^{19}$.

Dżabagina natomiast eksponuje przede wszystkim prawicowe i nacjonalistyczne odczytanie Sprawy Jakubowskiego w Polsce, by w konsekwencji pokazać, że właśnie taki odbiór przyczynił się do nieobecności Kalkowskiej w historycznoliterackim kanonie.

Część trzecia (Exodus) dotyczy doświadczenia wygnania, ucieczki i utraty, jest opowieścią o uchodźczych latach Kalkowskiej (1933-1937), spędzonych w Paryżu i Londynie w środowisku, które historycy literatury określają - za Erhardem

${ }^{18}$ "W Niemczech weimarskich artysta chciał nie tylko modernizować i rewolucjonizować sztuki piękne w ich wymiarze artystycznym czy technicznym, ale mieć realny wpływ na kształtowanie postaw i mentalności; uczynić sztukę nie tylko nośnikiem wartości estetycznych, ale także treści społecznych. Sztuka miała docierać do wszystkich warstw ludności, być przez nie rozumiana i «użyteczna», a nie służyć wyłącznie rozrywce i schlebiać gustom wybranych czy, w najlepszym razie, być narzędziem propagandy. W Niemczech podjęto próbę wprzęgnięcia twórcy w życie społeczno-polityczne: wielu lewicowych artystów zaangażowało się w ruch rewolucyjny i socjaldemokratyczny", Magdalena Cześniak-Zielińska, "Między sztuką i polityką: Awangarda artystyczna wobec zmian społeczno-politycznych w Republice Weimarskiej", Annales Universitatis Mariae Curie-Skłodowska. Politologia 21, nr 2 (2014): 206.

19 Michalczyk, ,Sprawy polsko-niemieckie”, 223. 
Bahrem - jako formację „modernizmu uchodźczego”. Ten okres życia autorki Głodu życia, rozpoczął się aresztowaniem, koniecznością opuszczenia Republiki Weimarskiej, rozczarowującym pobytem w Paryżu, wreszcie osiedleniem w Londynie:

Dopóki pisarka posiadała swoją lokalną afiliację w postaci Berlina, dopóty niepodważalnie była traktowana jako autorka weimarska, niezależnie od jej polsko-niemieckiego pochodzenia. W sytuacji utraty tego punktu zaczepienia brak jednoznacznej przynależności niemal natychmiast spowodował jej marginalizację: jako obywatelka polska nie była już wystarczająco „niemiecka”, by móc pozyskać wsparcie (bądź wzbudzić zainteresowanie przyszłych germanistów, zajmujących się uchodźcami z Trzeciej Rzeszy); jako niemieckojęzyczna pisarka, która większość swojego życia spędziła w weimarskim Berlinie, nie była też wystarczająco „polska”, by zaliczyć ją do kręgów londyńskiej Polonii (271-272).

Borykanie się z kłopotami finansowymi oraz znalezienie się na marginesie życia artystycznego zmusiły Kalkowską do poszukiwania nowych sposobów twórczej aktywności. W Londynie udało się jej nawiązać współpracę z rozgłośnią B BC, a także wystawić na West Endzie nową sztukę Sein oder Nichtsein na motywach procesu terrorystki Arlette Toison. Lata tułaczki nadwyrężyły zdrowie pisarki, a choroba tarczycy zmusiła ją do poddania się operacji. W wyniku powikłań po zabiegu zmarła w 1937.

Książka Anny Dżabaginy w intencji autorki ma być nie tylko gestem przywracania pamięci, ale także próbą przywrócenia proporcji pomiędzy biografią a dziełem Eleonory Kalkowskiej: warszawska badaczka buduje portret pisarki i jej twórczości, a zarazem miejsc, czasów i środowisk, w których działała. Mamy przy tym do czynienia z pracą naukową, z publikowaną wersją rozprawy doktorskiej (ten pierwotny charakter dysertacji na stopień naukowy nie wszędzie udało się autorce ukryć), a nie z biografią.

Dżabagina zebrała całkiem spory materiał na temat bohaterki swojej pracy. Udało się jej także zaprezentować Kalkowską jako autorkę tekstów różnogatunkowych i różnorodnych, znacznie wykraczających poza wąskie ramy kategorii Zeittheater. Zgromadzone źródła stały się podstawą do stworzenia refleksyjnego portretu. A jednak momentami sposób prezentacji materiału rozczarowuje. Jakby autorkę monografii bardziej interesowało to, co działo się wokół Kalkowskiej, a nie to, co w niej, niewiele na przykład dowiemy się o jej relacjach z bliskimi. Dżabagina starannie unika też tematu religijności bohaterki, wręcz sugeruje jej ateizm, a ze wspomnień córki wiadomo, że była osobą głęboko wierzącą. Badaczkę zdaje się bardziej pociągać rzeczywistość otaczająca pisarkę, nie zaś drążenie jej osobowości, które zaowocowałoby stworzeniem zindywidualizowanego, pogłębionego portretu. Dlatego postać Kalkowskiej gubi się czasami w rozbudowanych dywagacjach i porównaniach, opisach tła i kontekstów. 
Dżabagina niestrudzenie podąża tropem swojej bohaterki, szukając zapomnianych tekstów, porządkując fragmentaryczne dane biograficzne i zdobywając nowe. Zaznacza, że zależy jej na tym, aby obalić utrwalone przez lata sądy na temat życia i twórczości Kalkowskiej. Udaje się wydobyć na światło dzienne wiele informacji dotychczas nieznanych, zweryfikować błędne tezy stawiane przez badaczy, odkryć nieznane rękopisy, ustalić chronologię powstawania poszczególnych dzieł, dokonać rekonstrukcji dziejów rodziny - i to właśnie uznałabym za największą wartość prezentowanej publikacji. Badaczka wskazuje jednocześnie na deficyt źródeł (albo niemożność weryfikacji niektórych wobec braku innych śladów). Te fragmenty życia bohaterki, które nie znalazły potwierdzenia w materiale historycznym, zastępuje więc hipotezami, przypuszczeniami, domysłami. Podejmując próby wypełniania białych plam, luk w archiwach i źródłach, sugeruje możliwe wydarzenia, pomimo braku wiarygodnych dowodów czy nawet poszlak. „Nie wydaje się prawdopodobne”, „wszystko wskazuje na”, „nie sposób dociec”, „choć nie wiadomo dokładnie” - to tylko niektóre z licznych fraz wskazujących na niepewność autorki co do przyjętych wersji zdarzeń. W tym ujęciu biografia Kalkowskiej przypomina dawną mapę, na której szczegółowo przedstawione zostały wybrane wycinki rzeczywistości, a duży obszar został zapełniony wyobrażeniami autorki.

W ogólnym rozrachunku nie można odmówić omawianej publikacji bardzo dużej wartości merytorycznej. Kalkowska opisana przez warszawską badaczkę to kobieta nowoczesna i niezależna, żyjąca potrzebą tworzenia i obcowania ze sztuką, to przede wszystkim artystka, Nowa Kobieta uparcie dążąca do samorealizacji, chociaż jej droga na literacki Parnas nie była łatwa. Książka Dżabaginy umieszcza biografię i twórczość Eleonory Kalkowskiej w nowych kontekstach. Wyłania się z niej postać barwna, aktywna w różnych środowiskach artystycznych i ten aspekt życiorysu pisarki wydaje się najbardziej interesujący.

\section{Bibliografia}

Cześniak-Zielińska, Magdalena. „Między sztuką i polityką: Awangarda artystyczna wobec zmian społeczno-politycznych w Republice Weimarskiej". Annales Universitatis Mariae Curie-Skłodowska. Politologia 21, nr 2 (2014): 205-225. https://journals.umcs. pl/k/article/view/54t

Dżabagina, Anna. Kalkowska: Biogeografia. Gdańsk: Fundacja Terytoria Książki, 2020.

Gołaczyńska, Magdalena, Justyna Kowal i Piotr Rudzki, red. Teatr zaangażowany w Polsce i na świecie: Wrocławski Zeittheater. Kraków: Universitas, 2021.

Hernik Spalińska, Jagoda. „Eleonora Kalkowska - przywracanie pamięci”. W: Eleonora Kalkowska, Sprawa Jakubowskiego, Doniesienia drobne: Dramaty, 3-18. Warszawa: Instytut Teatralny im. Zbigniewa Raszewskiego, 2005.

Kowal, Justyna. Wstęp do: Gołaczyńska et al., Teatr zaangażowany w Polsce i na świecie, 5-11. 
Ławnikowska-Koper, Joanna. „W obronie sprawiedliwości: Eleonora Kalkowska (1883-1937) - między Warszawą a Berlinem”. Roczniki Humanistyczne 63, z. 5 (2015): 143-158. http://doi.org/10.1829o/rh.2015.63.5-10.

Michalczyk, Barbara. „Sprawy polsko-niemieckie wokół Sprawy Jakubowskiego Eleonory Kalkowskiej”. W: Gołaczyńska et al., Teatr zaangażowany w Polsce i na świecie, 213-225. Rybicka, Elżbieta. „Auto/bio/geografie”. Białostockie Studia Literaturoznawcze, nr 4 (2013):

7-23. http://bsl.uwb.edu.pl/bsl4.php.

Rybicka, Elżbieta. Geopoetyka: Przestrzeń i miejsce we współczesnych teoriach i praktykach literackich. Kraków: Universitas, 2014.

Rybicka, Elżbieta. „Miejsce, pamięć, literatura (w perspektywie geopoetyki)”. Teksty Dru-

gie, nr 1-2 (2008): 19-32. https://rcin.org.pl/dlibra/publication/66854/edition/50782.

Utracka, Dorota. „Parodie transmedialne: Tekst kultury jako kod nomadyczny”. W: Noma-

dyzm i nomadologia: Rozważania i analizy, redakcja Aleksander Kiklewicz i Arkadiusz

Dudziak, 77-101. Olsztyn: Centrum Badań Europy Wschodniej, 2018.

Węgrzyniak, Rafał. „Eleonora Kalkowska”. Zeszyty Literackie 93, z. 1 (2006): 209-221.

\section{Abstrakt}

\section{Przemieszczenia Eleonory Kalkowskiej}

Artykuł jest krytycznym omówieniem książki Anny Dżabaginy Kalkowska: Biogeografia (Warszawa 2020). Autorka umieszcza monografię w kontekście najnowszych studiów nad twórczością i biografią tej polsko-niemieckiej pisarki. Omawia wpływ inspiracji metodologicznych - zwłaszcza exile studies, geopoetyki i krytyki feministycznej - na sposób ujęcia materiału. Podkreśla szeroki zakres kwerend archiwalnych i badań źródłowych, komentuje sposób prezentacji źródeł oraz wybór kontekstów historycznych i kulturowych. Za najważniejsze zalety pracy uznaje poszerzenie i weryfikację dotychczasowej wiedzy o Kalkowskiej oraz umieszczenie jej twórczości i biografii w ramie modernizmu uchodźczego.

\section{Słowa kluczowe}

Eleonora Kalkowska, literatura polsko-niemiecka, modernizm, biografia, geopoetyka, transkulturowość, krytyka feministyczna, teatr zaangażowany

\section{Abstract}

\section{The Displacements of Eleonora Kalkowska}

This article offers a critical discussion of Anna Dżabagina's monograph Kalkowska: Biogeographia [Kalkowska: A Biogeography] (Warsaw 2020) in the context of the newest research on the work and life of the Polish-German author Eleonora Kalkowska. The reviewer discusses the influence of Dżabagina's methodological inspirations - especially Exile Studies, geopoetics and feminist criticism - on the way the material is approached. She emphasizes Dżabagina's extensive archive research, comments on her presentation and problematization of the sources, as well as her choice of historical and cultural contexts. 
According to the reviewer, the greatest merit of the book is that it broadens and verifies what has been known about Kalkowska to date, and places her work and biography in the context of exile modernism.

\section{Keywords}

Eleonora Kalkowska, Polish-German literature, modernism, biography, geopoetics, transculturalism, feminist criticism, socially engaged theater

\section{TATIANA CZERSKA}

dr hab., profesorka w Instytucie Literatury i Nowych Mediów na Wydziale Humanistycznym Uniwersytetu Szczecińskiego, literaturoznawczyni. Prezeska szczecińskiego oddziału Towarzystwa Literackiego im. Adama Mickiewicza. Zainteresowania badawcze: literatura polska xx i xxı wieku, autobiografizm, biografistyka, epistolografia, krytyka feministyczna. 